chæte fauna of this country. A few local names are in use, such as dew-worm, brandling, lob-worm, and cockspur, but these are as valueless for scientific purposes as cuckoo-flower or bachelor's buttons would be to a botanist.

It will be some time before my volume on British earthworms is published by the Ray Society. In the meantime, will not some publisher undertake to issue a small popular handbook of British worms, with illustrations, at a shilling? We have about fifty earthworms in this country, but only a dozen or so are by any means common, and it would be very easy for our working naturalists to get a grip of the subject, and thereby render immense service to a branch of science which is of the utmost practical value. Though I have written a large number of articles on our Annelids during the past thirty years, there is nothing on the subject which is available in a popular and handy form for would-be students, and in this matter such a handbook is sadly overdue.

May I venture once more to appeal to readers of NATURE for specimens of luminous worms or other creatures, as well as for rare, unusual, or abnormal forms, that would merit attention in my Ray Society monograph?

Cathay, Solihull, November 6 .

\section{The Doubly Refracting Structure of Silica Glass.}

IN an interesting letter on the above subject in NATURE of October 23 Lord Rayleigh mentions that, when used with accurately crossed Nicols, "a circular disc of optical quality silica showed a spiral structure." Upon reading this letter I was reminded of a very interesting colour effect I saw several years ago in fused quartz which had been acted on by the rays from radium. As is well known, crystalline quartz assumes a uniform yellowish-brown or brownish-red colour when "rayed" by the rays of radio-active substances; the formation of coloured streaks and of patches similar to the markings of marble has also been observed. On the other hand, fused quartz generally assumes a uniform brownish-violet colour when exposed to radium rays.

In his work preparatory to the determination of the atomic weight of radium, Hönigschmid (Wien. Ber., cxx., I6I7, I9II) used fused quartz evaporating basins for recrystallising large quantities of radium chloride, and these afterwards showed a remarkable spiral coloration. Radiating from the centre of each basin was a series of spiral-shaped streaks of a dark violet colour, which continued in many cases almost to the top of the basin. Their upper extremity would undoubtedly be limited by the height to which the radium chloride solution had occupied the vessel. The space between the streaks showed little or no coloration. As is usual in such cases, the coloration disappeared on heating the dishes in a Bunsen flame, a brilliant bluish-violet luminescence being produced.

It has generally been assumed that the conditions in the quartz which give rise to these "streaks" are connected with the mode of manufacture of such vessels, and I believe the above colouring effects may be of interest in view of Lord Rayleigh's interesting observation of the "optical heterogeneity" of silica glass.

ROBERT W. LAWSON.

The Phvsics Laboratory,

Sheffield University,

October $3 \mathrm{I}$.

The Antiquity of Man.

In the altogether excellent jubilee number of $\mathrm{N}_{\text {ATURH }}$ (No. 2610, vol. civ.) there is, I notice, a short paper entitled "The Antiquity of Man" contributed by Dr.
A. Smith Woodward. We are told in this paper (p. 2I2) that "as discoveries progress it becomes increasingly clear that true man, of the family Hominidæ, cannot [the italics are mine] be earlier than Late Pliocene or the dawn of the Pleistocene." We learn also that "so long ago as I880" Sir William Boyd Dawkins, "for other reasons," came to the same conclusion.

As your readers are doubtless aware, the question as to when man first appeared upon this planet has always been of what may be termed the "vexed" order, and generally regarded as unsettled.

But though it may be the opinion of Dr. Smith Woodward and of Sir William Boyd Dawkins that "true man" cannot be of a greater antiquity than "Late Pliocene or the dawn of the Pleistocene," it does not necessarily follow that such an opinion is correct. The chief evidence upon which the idea of the great antiquity of the human race is based-evidence not mentioned in Dr. Smith Woodward's article-is that afforded by the various implements of flint and other rocks which have been found embedded in certain Pliocene and Pleistocene strata. These humanly fashioned stones are com: paratively numerous, and afford evidence of a more complete type than is provided by the "few fragments of apes and man " which have hitherto been recovered from ancient deposits.

In view also of certain discoveries made in suffolk since I909 (described by Sir Ray Lankester and by myself), and the results of the excavations carried out during the last twelve months in the Red Crag at Foxhall, near Ipswich, I would venture to resard it as highly probable that a type of man capable of flaking flints in a clearly dexterous manner was present in that part of the country not later than Middle Pliocene times, and possibly even earlier. Further, these discoveries have demonstrated that, as would be expected, these Mid-Pliocene individuals were preceded by an earlier race or races of people who fashioned their flints in a less skilful manner. But whether these ancient flint-flakers were "true" men or not I am quite unable to say. I should imagine, however, that, judging from the kind of implements found, they had attained to a status far above that of any known ape.

It is clear, then, that Dr. Smith Woodward's views, as expressed in the jubilee number of Nature, upon the antiquity of man do not coincide with those of many of us who have made a study of early flint implements. Moreover, the fact that such widely divergent views upon this question are possible shows the urgent need for further research, especially as the present palæontological evidence, upon which Dr. Smith Woodward's opinions are founded, is, from its very nature, largely negative in character.

\section{J. REID MoIr.}

I THINK our present knowledge of the facts and principles of palæontologv justifies the statement I made. I intentionally omitted all reference to chipped flints because I regard them as inconclusive evidence.

$$
\text { A. SMith WoOdWARD. }
$$

\section{WESTERN TURKESTAN.}

$\mathrm{W}$ ESTERN TURKESTAN has been, for all practical purposes, a closed land ever since the final subjugation of the Turkomans by Skobeleff in r880. Political conditions made it difficult for Europeans, and particularly for British, to travel in the province. It was reserved for the

$$
\text { NO. } 26 \mathrm{I}_{3} \text {, VOL. IO4] }
$$

